\title{
Friends of the Library
}

This study of Friends of the Library groups is based on a survey, conducted during the spring of 1974, with usable positive responses from sixty-four academic, public, and special libraries. The study includes an examination of the origin, objectives, and government of Friends groups; an analysis of the structure of membership and membership size in relation to the size of library or institution and to income; and a discussion of annual revenues, activities of Friends groups, including publications, library support for Friends groups, and various problems encountered.

T

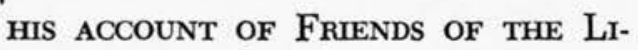
BRARY GROUPS is based on a report prepared in the spring of 1974 for the Tulane University Library, which was at the time planning to establish such an organization. Of particular interest were such areas as the origin of Friends groups, their objectives, membership structure, dues and revenues, publications, activities, and accomplishments. These questions were incorporated into a questionnaire, along with a request for any available documentation: constitutions, publications, invitations, and advertisements. ${ }^{1}$ The questionnaire was sent out by the Systems and Procedures Exchange Center (SPEC), an organization operated by the Office of Management Studies of the Association of Research Libraries. The questionnaires were sent out to eighty-eight SPEC member libraries, as well as to a Tulaneselected list of public libraries (43), small university libraries (15), and spe-

Ann Gwyn, Anne McArthur, and Karen Furlow are librarians at Tulane University Library, New Orleans, Louisiana. The authors acknowledge the assistance of Sarah Churney in the gathering of data on which this article is based. cial libraries (13), a total of 159. SPEC issued a brief report of the information received from its member libraries, ${ }^{2}$ and this article is a more detailed account of the results of the survey, including information received from non-SPEC libraries.

The general response to the questionnaire was good, with 129 of the 159 being returned. Of these, 57 percent replied that they did have a Friends group. Fifty-six percent of the college and university libraries surveyed, 60 percent of the public libraries, and 54 percent of the special libraries have such organizations. The following analysis is based on sixty-four usable positive returns, of which 59 percent were from college and university libraries, 34 percent from public libraries, and 7 percent from special libraries.

\section{OrigINS}

The earliest Friends organization was started in 1923 and the next not formed until 1930. What is especially striking is the large proportion of groups (28 percent) which have started since 1970. It seems that many libraries, feeling financial pressures, are looking for ways to supplement their budgets. 
Of all libraries surveyed, 55 percent were involved in starting their own Friends groups. Sixteen percent of these groups were started entirely by the library staff and 39 percent begun jointly by the library and other interested people. Forty-five percent of Friends groups were started solely by interested individuals from outside the library. In university libraries 12 percent of the Friends groups were started by the library itself and 40 percent in conjunction with interested people. Forty-eight percent of university Friends groups were started by interested people alone. By far the largest group of interested people in university Friends groups was faculty and alumni, with book collectors running a poor third. (Civic leaders and business people were mentioned several times each and students twice.) In university libraries there seems to be a clear pattern of Friends groups starting from within the library itself, with the active support of the faculty and alumni, or the faculty and alumni working alone.

In public libraries the pattern is slightly different. Forty-eight percent of Friends groups connected with public libraries were started by the library alone or with the help of interested people. The interested people connected with initiating public library Friends come from quite different groups, as might be expected, the most active being civic leaders, with business people, book collectors, and women's clubs following some distance behind. Of the five special libraries responding to this question, three Friends groups were started by the library alone and two with the assistance of interested people.

\section{OBJECTIVES}

The questionnaire suggested three possible objectives for Friends groups: fund raising, developing support for the library, and advising the library administration. A space was also left for responding libraries to describe other objectives. Of the sixty-two libraries answering this question, forty gave as their objectives both fund raising and developing support (55 percent), and three, in addition, mentioned advising the administration. Twenty-three percent said that general support of the library was the sole objective of their Friends group, and only three libraries said fund raising was their sole objective.

Thirty-seven university libraries responded to this question. Sixty percent said that both fund raising and developing support for the library were purposes of their groups, and two mentioned advising the administration as well. Developing support for the library ( 25 percent), fund raising ( 9 percent), and acquiring funds and gifts for special collections ( 30 percent), were given as sole objectives. Other objectives mentioned were "promote culture," "promote town-gown relations," and "sponsor exhibits and lectures."

In the literature published by various university Friends groups the main purpose is often expressed in rather vague terms: "enrichment of the library" or "to encourage understanding and appreciation of the work of the library." The Harvard College Library Friends brochure explains the purpose of its Friends as being to acquire special purchases: "Friends income is devoted to acquisitions and to the Harvard Library Bulletin; none is used for bricks and mortar or housekeeping."

On the other hand, there are groups whose purposes appear to be rather different. The University of Massachusetts Library Friends invitation pamphlet puts it in this outspoken way:

The University of Massachusetts Library doesn't intend to compete with Princeton. It isn't dreaming of rare and expensive collector's editions. It does want primary source material in microfilm and other formats. And although its most urgent need is money, it 
would welcome the donation of university-level books, periodicals, and other materials.

The University of Houston Library Friends states its main purpose simply as "Development of the Library," and proceeds to show how a fifteen dollar contribution can pay for the purchase and cataloging of a circulating book. It also publishes a "Selected List of Current Gift Opportunities," not the more usual desiderata list of rare items, but works on all subjects, many of them standard reference works needed by the library, ranging in price from $\$ 12,000$ (a German work on inorganic chemistry), to $\$ 50$ (a basic work in music). The National Women's Committee of Brandeis University, a unique national Friends group with 65,000 members, has as its purpose: "The support of the Library." (It does, in fact, fund over half the total library budget. $)^{3}$

In the constitution and bylaws of Friends groups there is almost always a statement of purpose and objectives. These statements are generally quite short, often only one sentence, and they mention some or all of the following points: to bring together people interested in books; to promote and publicize the interests, usefulness, and resources of the library facilities through publications, programs, exhibits, and other means; to secure gifts and bequests and to provide funds for the purchase of material for the library.

\section{Constitution and Government}

Thirty-five university and public library Friends groups provided copies of their constitutions and/or bylaws. The basic provisions of the constitutions and/or bylaws for both university and public library Friends groups include clauses for the following: name, purpose, membership, dues, meeting, titles of officers and duties, composition of the board(s) and its duties, elections, committees, and handling of funds.
Seventy-one percent of public library Friends make provision for parliamentary procedure, while it is included in the documents of only 33 percent of the university groups.

The officer organization of the groups is fairly standard. SPEC concludes that:

$\ldots$ the standard president, vice-president, secretary-treasurer pattern prevails, often with the addition of an extra secretary or program chairperson. The governing board is usually composed of the officers and several board members, with the library director exofficio. $^{4}$

Within this typical officer format, there is some variation of titles and of numbers of officers. For the university Friends, the number of officers ranges from two to twelve, the average number four. Public library Friends in the sample have from four to seven officers, the average five.

All the Friends groups which sent constitutions or bylaws have a governing body of some kind in addition to the officers. About half of the university Friends and 21 percent of public library Friends have two governing bodies. One of these groups is variously called council, trustees, or board of directors. For university Friends, the membership of this body ranges from three to thirty-three, with an average of fourteen, while for public Friends the range is seven to forty-two, with an average of twelve. The function of this group is to govern between meetings of the Friends. Some organizations have a second governing body; its function is to direct the group between meetings of the board. This body is called the executive committee or executive board. Its membership is smaller than the board or trustees group, ranging from four to five members in university libraries and six to twelve in public.

When an executive committee exists as well as a larger board, its members are almost always members of the larg- 
TABLE 1

Stze of Membership and Szze of Library

\begin{tabular}{ccccc}
\hline \hline & $\begin{array}{c}\text { Library } \\
\text { Small Libraries } \\
\text { (under } 500,000 \\
\text { Volumes) } \\
\mathrm{N}=8\end{array}$ & $\begin{array}{c}\text { Medium Libraries } \\
(500,000-1,000,000 \\
\text { Volumes) } \\
\mathrm{N}=14\end{array}$ & $\begin{array}{c}\text { Large Libraries } \\
(1,000,000-2,000,000 \\
\text { Volumes) } \\
\mathrm{N}=17\end{array}$ & $\begin{array}{c}\text { Extra- } \\
\text { Large Libraries } \\
\text { (over 2,000,000 } \\
\text { Volumes) } \\
\mathrm{N}=17\end{array}$ \\
\hline $\begin{array}{c}\text { Range } \\
\text { Mean }\end{array}$ & $\begin{array}{c}85-2,400 \\
588\end{array}$ & $\begin{array}{c}111-800 \\
286\end{array}$ & $\begin{array}{c}73-2,000 \\
620\end{array}$ & $\begin{array}{c}77-1,650 \\
\mathbf{7 4 8}\end{array}$ \\
\hline
\end{tabular}

er board. There is considerable overlapping between the officers and the governing boards; 86 percent of the university Friends and 93 percent of public library Friends include all the officers in their governing boards.

\section{MEMBERSHIP}

Many invitations to membership are attractively, often elegantly, designed and printed. Most leaflets include a short statement of purpose and objectives, activities, and benefits of membership. Benefits may include invitations to various programs, exhibits, dinner meetings, as well as the receipt of a Friends publication. Borrowing privileges are only occasionally offered in college and university libraries; and in a few cases a discount at the university press is given to Friends members.

There is considerable uniformity in the membership composition of Friends groups. In university libraries the largest single group is made up of faculty members, followed closely by alumni. Student memberships are far fewer, approximately a third that of the faculty. Community professional people, civic leaders, and book collectors are all well represented on university Friends groups in about equal numbers, and business people are a somewhat smaller group. Both public and special libraries have a fairly even distribution of members from civic leaders, community professionals, and business people, and a slightly smaller group of book collectors.

The size of the membership of a Friends group does not necessarily cor- respond to the size of the library itself. Table 1 shows there is a wide range of membership size in each group; and the mean for small libraries is considerably larger than that of medium-size libraries. However, if the Huntington Library (with a membership of 2,400) included in the small libraries group is eliminated, the range would be 85 to 550 and the mean 329. This is still larger than the medium-size library membership mean, but more in line with a possible trend toward larger libraries having larger Friends memberships.

When the membership size is considered in relation to the type of library (academic, public, and special), there are more members in the Friends groups of public libraries and particularly of special libraries than even the largest university library, as is shown in Table 2. (If the outstandingly large group at Princeton is excluded [1,400 members], the range for colleges and small universities would be 151 to 800 , with a mean of 392 .)

It can be seen from Tables 1 and 2, however, that there is no strong relationship between size of library and Friends membership, or size of university and size of membership. For example, in Table 2 , one would expect about twice the average membership size for the extra-large university group, if the relationship between the size of membership and the size of university were a strong one, even accepting the 392 mean for small universities.

There is a bewildering array of names for types of membership dues in 
TABLE 2

SIZE of Membership and Type of Institution

\begin{tabular}{|c|c|c|c|c|c|c|}
\hline Membership & $\begin{array}{c}\text { College and } \\
\text { Small University } \\
\text { (under 10,000 } \\
\text { Enrollment) } \\
\mathrm{N}=9\end{array}$ & $\begin{array}{c}\text { Medium University } \\
(10,000- \\
20,000 \\
\text { Enrollment) } \\
\mathrm{N}=15\end{array}$ & $\begin{array}{l}\text { Institution } \\
\text { Large University } \\
(20,000- \\
30,000 \\
\text { Enrollment }) \\
N=5\end{array}$ & $\begin{array}{c}\text { Extra-Large } \\
\text { University } \\
\text { (over } 30,000 \\
\text { Enrollment) } \\
\mathrm{N}=4\end{array}$ & $\begin{array}{l}\text { Public } \\
\text { Library } \\
\mathrm{N}=16\end{array}$ & $\begin{array}{l}\text { Special } \\
\text { Library } \\
\mathrm{N}=5\end{array}$ \\
\hline $\begin{array}{l}\text { Range } \\
\text { Mean }\end{array}$ & $\begin{array}{c}151-1,400 \\
504\end{array}$ & $\begin{array}{c}111-650 \\
342\end{array}$ & $\begin{array}{c}98-1,650 \\
527\end{array}$ & $\begin{array}{c}77-17,000 \\
596\end{array}$ & $\begin{array}{c}73-2,000 \\
661\end{array}$ & $\begin{array}{c}250-2,400 \\
1,263\end{array}$ \\
\hline
\end{tabular}

Friends groups, which vary not only from one group to another, but also within each group. Most groups have at least four categories of membership, although some have just one, and others have no categories at all. Two-thirds of the university Friends groups have four or more categories of membership, and one-third have special student memberships. Public libraries are more evenly divided between those which have four or more categories and those which have less than four. Special libraries tend to have only one category, although three have four or more.

There are seven main dues categories among the Friends organizations. In the student group, the mean for dues is $\$ 3.91$; in the regular member category, the mean is $\$ 12$. In the subscriber or contributing member group, the mean is $\$ 29$, and in the sustaining or sponsor group the mean is $\$ 70.33$. The next level is the patron; this category also includes industrial, family, and institutional memberships, with mean dues of $\$ 231$. The two membership categories with the highest dues are the benefactor, with a mean of $\$ 500$, and the life member, with a mean of $\$ 1,038$.

In terms of what appear to be the financial objectives of the various types of memberships, these categories can be arranged in three major groups: (a) regular membership, aimed at attracting the general public; (b) student membership, based on the assumption that students cannot afford regular dues; and (c) special membership, aimed at the generous and wealthy, as well as organizations, such as business firms or institutions.

\section{Revenues of Friends Groups}

Dues supply the main steady income for any Friends group. Fund raising drives and gifts generally bring in more money, but these are spasmodic and unpredictable. Dues, although they do vary from year to year, can generally be forecast, especially after an organization has been in existence for some time. Also, the income from dues is unrestricted, except in the cases where a certain percentage is allocated for a Friends publication. Cash gifts, on the other hand, may often be restricted and to be used only in accordance with the donor's wishes. Dues, therefore, like tuition to a private university, are a very important source of income, especially to a new Friends group, which as yet has no endowment funds.

Forty-three Friends groups in the survey gave a breakdown of their dues structure, showing how many members belong in each category. From this information it was possible to determine the approximate annual income received by these groups from dues. On the whole, there is a positive relation between the size of membership and income from dues. The smallest group, with seventy-three members, reported an annual income of $\$ 850$, and the largest group, with 2,400 members, an annual income of $\$ 98,250$. However, there were some noticeable exceptions to this gen- 
eral trend. Some groups with roughly the same size membership reported very different incomes; and, conversely, groups with the same income reported very different size memberships. Generally, the reason for this seems to be that those groups with a few dues in the "benefactor" or "patron" category have a larger income than similar sized groups without members in such categories. Even ten or twelve $\$ 100$ or $\$ 500$ dues are a tremendous boost to the annual income of a group.

It appears from the results of the survey that Friends groups which have several members in high paying membership categories, and which do not have a regular dues category lower than the national mean of $\$ 12$, stand a better chance of having a larger income than those larger groups with smaller regular dues and almost no "benefactors" or "patrons." A large membership of about 450 or more is generally an indication as well of a large income.

In addition to revenues from dues, Friends groups also receive gifts in cash, often in the form of memorial gifts or money from special fund drives. The question concerning revenues in the questionnaire was the most unsatisfactorily answered. In reply to the question, "What revenues are brought in by the Friends' organization?" only 39 percent answered in terms of cash. The majority wrote such comments as: "Dues and book sales," or "Memorial gifts." In most cases, it has been possible to calculate dues, but there was no means of determining the income from memorial gifts or book sales. A few groups sent financial reports, which were very helpful. In light of these limitations, the following discussion must be considered only as an approximation of revenues.

Memorial gifts are a major source of revenue of Friends groups and in many instances, the largest single source of funds a group receives. Some such gifts are given as outright sums to be spent immediately; others are given in the form of endowments. Many memorial gifts are restricted by the donor to be spent for a certain type of item, most often a rare book or manuscript.

Gifts of money, not given as a memorial, are also received by Friends groups. These gifts can be restricted or not, depending on the donor's preference and the persuasion of the recipient. Because of the unpredictable nature of gifts, income for the group will fluctuate from year to year. Thus, income and the success of a Friends group should not be judged by its performance for one year but rather on a longterm basis.

Many groups organize annual fund drives, such as book sales, as a part of their membership activities. A book sale can yield anything from $\$ 450$ to $\$ 5,000$ or more, depending on the size and nature of the sale. Some groups have auctions of rare books donated by members, and others sell duplicates from the library's holdings. Another type of small fund drive is the membership drive, which ultimately brings in dues if it is successful.

Large fund raising campaigns have been held, or are currently being held, by 17 percent of the libraries in the survey, of which the majority are university groups. This type of fund drive is not an annual affair, but rather a rare occasion often organized to raise money for one specific purpose: an endowment fund, a new building, an extension to, or renovation of, an old building. For example, New York University Library Friends recently raised $\$ 30,000$ for a Friends' board room in the new library building (1973). Not all drives have a single goal, however. The University of Houston Library Friends raised \$86,767 in a "fund drive for library excellence" campaign in 1972-73, and Duke University Library Friends is currently sponsoring a $\$ 250,000$ campaign for the li- 
brary. Large fund drives like these involve a great deal of work and dedication, but if successful, they provide a much larger sum of money than could possibly be raised by dues, or by activities of a Friends group.

The total income of Friends for the year 1972-73 has been estimated to give an idea of the revenues they receive. These figures were taken from twentyfive libraries; they include at least two groups which had fund raising campaigns at that time. In the under 500 membership category, the income ranged from $\$ 1,200$ to $\$ 86,000$, with a mean of $\$ 39,931$. This figure includes the two groups with fund raising campaigns just mentioned; if these are eliminated, the mean would be $\$ 12,747$, which is probably a closer estimate of what this size group could expect annually without any special fund drives. In the 500 to 1,000 membership category, the income ranged from $\$ 7,000$ to $\$ 28,000$, with a mean of $\$ 20,195$. For the over 1,000 membership category, the range of the income was $\$ 11,000$ to $\$ 550,000$, with a mean of $\$ 175,855$. These figures represent an approximation; it must be remembered that the figures for one year cannot be taken as an example of every year.

Money raised by Friends groups is used in various ways. Obviously, a certain amount has to go back into the organization for operating expenses, such as advertising, invitations, postage, printing, etc. Publication of a newsletter or a journal is another frequent expenditure. The questionnaire mentioned three possibilities (with a blank for others) for the use of income: special projects, general budget, and special collections. Twenty-one percent said they spent their entire income, after operating expenses, on special collections, 32 percent included special collections in their expenditures, and 41 percent mentioned special projects. The latter included almost anything, from buying equipment to building a library. Several groups mentioned placing some of their income into an endowment fund. Many groups have a savings account into which they deposit a certain amount every year.

\section{LiBRaRy SUPPORT}

A large majority of libraries give administrative support to their Friends groups ( 83 percent). In most cases this consists of a liaison officer in the library sitting on the board of the Friends. In some instances this officer is the secretary-treasurer of the group; in at least two cases this person edits a Friends publication, and in others advises on selection of gifts. Most frequently this liaison officer is the director of the library, but the officer may be an associate or assistant director, a member of the special collections division, or a member of the institution's gift department.

Most libraries also give clerical assistance to their Friends groups (78 percent), and over half give office space within the library (60 percent). One library reported giving one full-time position to the Friends for clerical assistance, and another gave one half-time position. Financial support was not at all common (only 18 percent), and of these several stated only partial support. Several libraries reported that they gave some financial help at the beginning to get the organization on its feet. The amount of support given by university and public libraries to their Friends groups is very similar, except that public libraries tend to provide office space more frequently than university libraries.

It is quite clear that very few Friends groups function without a great deal of support from their libraries. In most cases not only are some staff members involved in the activities and running of the Friends group, but office space and clerical help provided by the library are also very common. Financial help is unusual, except to start off a new Friends. 


\section{Activities}

The term "activities" here refers to events held by the Friends, including small annual fund drives. Special large fund raising campaigns and also publications sponsored by Friends groups are discussed elsewhere in this article.

The activities of Friends groups can be divided into two basic types: those events put on for the enjoyment of the Friends members (receptions, dinners, exhibits, etc.) and those events sponsored by the Friends to raise money (book sales, card sales, etc.). Almost all Friends groups have at least one meeting a year. This is generally an annual membership meeting, often a luncheon or dinner with a speaker, or less often, a reception or just a speaker. Other than the annual meeting, by far the most popular type of entertainment for university groups is a program with a speaker, and then exhibits, with or without a reception. Student book collecting contests, library tours, open house, Friend of the year awards, and concert series were all mentioned as entertainment activities, though far less frequently than speakers and exhibits. Most university groups sponsor three or four such activities a year, although 27 percent meet only once, and several meet more than four times. In addition to these meetings, some kind of fund drive is usually held to raise money or increase membership.

The emphasis of the activities of public libraries Friends groups is somewhat different from those in universities. Community services, such as service to shut-ins, out-reach programs, a scholarship for a student to attend library school, and concerts and film shows predominate in public libraries. A program with a speaker, occasionally combined with a luncheon, was the most popular type of annual membership meeting mentioned. Annual dinner meetings were rare, as were exhibits and recep- tions. However, fund raising activities were very similar to those in university groups. Some form of book sale or fair was held by 86 percent of public library Friends groups. Special libraries concentrated on receptions, exhibits, and tours. None had book sales, and only one mentioned fund raising.

In response to a question on publications, many libraries provided examples of their journals, newsletters, exhibition catalogs, and other materials. Ten of the sixty-four respondents have no official publication sponsored by their Friends group. Of the libraries surveyed, 15.5 percent of university library Friends groups do not publish, and 20 percent of the public library groups do not publish. All of the special libraries surveyed have some type of publication.

The most frequent example of a Friends publication, other than promotional literature concerning membership, discussed earlier, is a journal, a bulletin, or a newsletter. Several Friends groups publish more than one of these. Journals, the most scholarly type of Friends publication, usually appear three or four times a year and generally contain articles pertaining to the collections in the library. The Princeton University Library Chronicle is a particularly fine example; in an elegant and scholarly way it is able to transmit to any interested reader information about the collections in the Princeton Library. The journal is sent to all Friends of the Princeton Library as part of their membership benefits.

Another type of Friends publication is the bulletin or newsletter, which usually includes short notes on Friends events and news of recent acquisitions. The newsletter or bulletin is usually published monthly or bimonthly and is sent to all members, though it is not usually sold by subscription.

Friends groups also publish various occasional publications: descriptive brochures of the library publicizing the ex- 
tent of its collections, exhibition catalogs of library displays, collections of speeches given before a Friends group, and cards or calendars drawing on library material. Keepsake publications, issued to commemorate a special event, are used particularly by university groups and make an attractive incentive for joining the group.

Almost all groups publish some kind of annual report, ranging in style and format from an attractive printed booklet to a typewritten sheet. It is the annual reports which give the detailed accounts, both financial and social, of the Friends, as well as the major accomplishments for the year. Some groups, like the Detroit Public Library Friends, publish their annual report as an issue of their occasional publication.

Publications are a very important outcome of Friends groups. It is through them that the Friends can convey to the outside world what kind of material is stored away in the library, material which otherwise would only be known to a specialized circle of scholars and librarians. Publications focus attention on the library with the result that more people, becoming aware of the library's needs, interests, and growth, are not only benefiting from its existence, but are also more likely to give help.

\section{Problems AND ACCOMPlishments}

As with any organization, Friends of the Library groups have various problems, although these do not seem to be overwhelming. In fact, 45 percent said they have encountered no problems at all, and of those who did several explained the problems were minor. University and public libraries showed similar percentages with and.without problems (slightly more with than without), and only special libraries, always rather different, had a larger proportion without problems.

The most prevalent difficulty in university and public library groups seems to be lethargy among the membership. This may take the form of poor attendance at meetings, lack of volunteers to help with projects, lack of decisive leadership and initiative, and too much dependence on the library liaison officer for guidance, organization, and support. This often creates a burden for the library, both for the liaison officer and for two or three members of the library staff. This particularly seems to be the case for the staff of university libraries, who made frequent comments in the questionnaires about the fact that the organization lagged without constant support from the library staff.

Another recurrent problem is the need for a larger membership. Many groups would simply like to have more members, and others want to recruit more of certain types of members, such as corporate members or students. Many groups have special membership campaigns and drives to try to overcome this problem.

A few groups mentioned having financial problems, generally meaning that it was difficult to carry out projects already planned, such as funding a publication or special event. Various conflicts were reported: between members themselves about goals of the Friends; between the Friends and the university administration; or between the Friends and the library administration. Other problems included a lack of faculty support, an organizational problem, a lack of donations, a lack of good projects, suspicion of some library staff because of a tendency to concentrate on rare materials, and one unusual problem at the Huntington Friends of a lack of seating space for the large attendance at meetings!

Despite these various problems, the majority of libraries seemed to feel that the Friends were worthwhile, and it should be remembered that only a little over half of the groups surveyed admitted to having any problems at all. 
Accomplishments in Friends groups are many and varied. The questionnaire suggested three: fund raising, acquisition of special collections material, and development of community support for the library. There was also a blank for other responses. All libraries, except three, said that one of their major achievements was acquiring items for special collections, either as gifts or purchases. A large majority considered fund raising to be another important accomplishment. This has been achieved in varying degrees, as already discussed above. Only a little over half the libraries surveyed (53 percent) considered themselves to have achieved development of community support for the library. As Edward Holley has written:

This support does not come automatically. The story of the importance and usefulness of the library has to be told to the community, and for this we depend upon the library's Friends. If they do not tell the story, who will?5

Making the community aware of the needs of the library and of its vital importance to education is possibly one of the most difficult tasks of a Friends group. Once this is accomplished, then fund raising and acquisitions of all kinds become easier, as is shown in successful Friends groups, such as Brandeis, Detroit Public, Harvard, University of Houston, and Princeton, to mention just a few.

Concrete accomplishments of Friends groups have been discussed throughout this article: acquisition and gifts of both rare and nonrare materials; funds for building or renovating library buildings; funds for the establishment of an endowment; the purchase of equipment, especially in public libraries (copying machines, a mobile library); the development and support of a publications program; exhibits, lectures, concerts, and film showings; the establishment of the library as a cultural center for a university or other community.

Sometimes the generosity and efforts of a single Friend can greatly enhance a library's collection. Charles W. Mixer, in a striking example, has described how a Friend of the Columbia Library built up the Santayana Collection, started a Masefield Collection, and played the major role in raising funds from other donors to buy the collection of a nationally known book illustrator and type designer. ${ }^{6}$ Gifts in kind and the hard work of a Friend, such as this, are very important accomplishments of any Friends group.

Less tangible achievements are harder to assess. Benjamin E. Powell, librarian of the Duke University Library, expressed it in this way:

It is difficult to assess accurately the contributions of the Friends. Ideas planted by activities of the organization may not bear fruit for years. But Friends who attend meetings and hear about the Library's needs, and those who read the publications, are better informed about the Library's needs and more likely to include it in bequests. ${ }^{7}$

This statement comes from a librarian connected to a Friends group which plans to raise $\$ 250,000$ by the end of 1975 and has already raised $\$ 100,000$. It seems unlikely that this fund drive could have taken place without the conviction of the Friends that to support the library in every way possible is a very vital and important task indeed.

\section{Conclusion}

It seems clear from the evidence obtained in this survey that Friends organizations can be a considerable support to a library. The objectives of the group, of course, determine what the accomplishments are. The success of the group is dependent, to a large extent, on the efforts and the support of the library staff, especially the liaison officer. In university groups, some support 
from faculty, staff, and the university administration is also needed. A significant part of the community, including the university community, not only has to be aware of the library's needs, but it has to be persuaded that supporting the library with money, gifts, and hard work is rewarding and important. Dr. Louis B. Wright pointed out this importance some years ago:
In the collection and preservation of the raw materials of history, the benefactors of libraries are aiding in the transmission of learning to posterity. ... Although their benefactions will not excite the emotional acclamations of the multitude, they will subtly influence the future. Theirs is a valuable and enduring, if austere, philanthropy. ${ }^{8}$

\section{REFERENCES}

1. For information on similar surveys which have been conducted previously see Esther H. Dixon, "Friends of College Libraries," ALA Bulletin 33:84 (1939); M. Allyn Fox, "Friends of the Library Groups in Colleges and Universities," College of Research Libraries 12:353-54 (Oct. 1951); "A Survey of Origins, Structures, and Activities of Friends of the Library Groups," PLD Reporter, no.3:5-59 (June 1955) (this survey was conducted by the Public Libraries Division of ALA, in cooperation with the ALA Committee on Friends of Libraries); and Frank J. Dempsey, "Friends of the Library," in The Bowker Annual of Library and Book Trade Information, 1970 (New York: Bowker, 1970). The ALA Friends of Libraries Committee of the Public Relations Section, Library Administration Division, has conducted these and other surveys, as well as preparing an information kit concerning Friends groups and publishing several helpful guides, in particular: Sarah Leslie Wallace, ed., Friends of the Library: Organiza- tion and Activities (Chicago: American Library Assn., 1962).

2. "Friends of the Library Organizations," SPEC Flyer, no.6 (April 1974).

3. For a detailed account of this unusual group, see Louis Schreiber, "A Unique Friends of the Library Group," College d Research Libraries 16:365-67, 369 (Oct. 1955). A more recent report is "Friends are Money-Raisers," American Libraries 5:231 (May 1974).

4. "Friends of the Library Organizations," p.2.

5. Edward G. Holley, "University Libraries and the Friends," Texas Libraries 25:136-37 (Winter 1963).

6. Charles W. Mixer, "A Friends of the Library Group for my College?" College Library Notes, no.12 (Summer 1971).

7. In response to questionnaire on Friends of the Library, 1974.

8. Louis B. Wright, "Some Early 'Friends' of Libraries," Huntington Library Quarterly 2: 355-69 (April 1939).

\section{AdDitional References}

Frances J. Brewer, "Friends of the Library and Other Benefactors and Donors," Library Trends 9:453-65 (April 1961).

Catherine J. Butler, comp., Friends of the Library Groups (Public library ed.; Chicago: American Library Assn., 1951).

Friends of the Library: Who They Are, What They Do (Chicago: American Library Assn., 1949).

Wilmarth S. Lewis, "The Layman and Libraries," The Yale Review 36:456-65 (March 1947).
Errett Weir McDiarmid, "Friends and Libraries," Princeton University Library Chronicle 9:173-79 (June 1949).

Robert O. Schad, "Friends of the Huntington Library," Library Trends 5:483-88 (April 1951).

Lawrence S. Thompson, "Friends of the Library," American Library and Book Trade Annual, 1960 (New York: Bowker, 1959).

Willard Thorp, "The First Twenty-Five Years," Princeton University Library Chronicle 16: 157-65 (Summer 1955). 